\title{
CRIAÇÃO DE UM NOVO PARTIDO: JUSTA CAUSA PARA A INFIDELIDADE PARTIDÁRIA?
}

Creation of a new political party: just cause for political party infidelity?

Rodrigo Élcio Marcelos Mascarenhas

Leônidas Meireles Mansur Muniz de Oliveira

Resumo: Este texto objetiva apurar o posicionamento normativo, doutrinário e jurisprudencial em relação à fidelidade partidária quando um parlamentar, com mandato em exercício, busca a transferência para partido político recém-criado. A pesquisa parte principalmente da análise dos dispositivos legais aplicáveis à espécie, principalmente depois da edição da Lei Federal n 13.165, de 29 de setembro de 2015, que não prevê como justa causa, para mudança partidária, a criação de nova legenda. A abordagem tem caráter teórico argumentativo e utiliza a técnica de pesquisa bibliográfica e documental. Com base em doutrinas nacionais, estrangeiras, e na jurisprudência do Supremo Tribunal Federal e do Tribunal Superior Eleitoral, fica constatado alinhamento pela não admissão de transferência de partido baseada na hipótese de filiação a um partido novo, ensejando, portanto, a perda do mandato do parlamentar infiel.

Palavras-chave: Princípios constitucionais eleitorais. Sistema eleitoral proporcional. Minirreforma eleitoral. Inconstitucionalidade. Fidelidade partidária.

\begin{abstract}
This text aims to determine the normative, doctrinal and jurisprudential positioning about party loyalty when a member of parliament, with a current mandate, seeks the transfer to a newly created political party. The research is mainly based on the analysis of the legal provisions applicable to the species, especially after the publication of Federal Law number 13,165, dated September 29, 2015, which does not provide for just cause, for party change, the creation of new legend. The approach is theoretical argumentative and uses the technique of bibliographic and documentary research. Based on national and foreign doctrines and in the jurisprudence of the Federal Supreme Court and the Superior Electoral Court, it is verified alignment for the non admission of party transfer based on the hypothesis of new party membership, thus leading to the loss of the mandate of the unfaithful parliamentarian.
\end{abstract}

Keywords: Constitutional principles. Electoral proportional system. Electoral mini-reform. Unconstitutionality. Party loyalty.

Artigo recebido em 11 abr. 2018 e aprovado em 26 ago. 2019. 


\section{Introdução}

A Lei $n^{\circ}$ 13.165, de 29 de setembro de 2015, apelidada de minirreforma eleitoral, promoveu diversas alterações em leis eleitorais brasileiras. Entre elas, passou a dispor, em norma, as hipóteses de perda de mandato por infidelidade partidária, ao incluir, na Lei dos Partidos Políticos, o art. 22-A.

O dispositivo estabelece a perda de mandato do detentor de cargo eletivo que se desfiliar, sem justa causa, do partido pelo qual foi eleito. A norma ainda dispõe, em rol taxativo, as três hipóteses legais em que existirá a justa causa para a desfiliação partidária. São elas: a mudança substancial ou desvio reiterado do programa partidário; a grave discriminação política pessoal; e a mudança de partido efetuada durante o período de trinta dias que antecede o prazo de filiação exigido em lei para concorrer à eleição, majoritária ou proporcional, ao término do mandato vigente (Brasil, 2015).

Note-se que a criação de nova legenda não é abarcada pelo rol taxativo de hipóteses em que o parlamentar pode pleitear a transferência de partido. Situação que encontrava amparo na Resolução TSE n⿳o 22.610/2007, diploma que regulava a fidelidade partidária até a sanção da Lei n⿳⺈ 13.615/2015. Cabe ressaltar que as novas regras são objeto da Ação Direta de Inconstitucionalidade 5.398, proposta pelo partido Rede Sustentabilidade, em que foi deferida parcialmente medida cautelar postulada, a ser referendada pelo Plenário do Supremo Tribunal Federal, para restabelecer o prazo integral de 30 dias para que detentores de mandatos eletivos se filiem aos novos partidos registrados no Tribunal Superior Eleitoral (TSE), imediatamente antes da entrada em vigor da Lei $n^{\circ} 13.165 / 2015$. Os autos ADI n 5.398 estão conclusos ao ministro-relator Roberto Barroso desde 26 de novembro de 2015, portanto, a medida cautelar e tão pouco o mérito da ação chegaram à apreciação do plenário do STF.

No presente artigo, o objetivo é demonstrar a trajetória histórica, doutrinária, jurisprudencial e normativa acerca do entendimento a respeito da fidelidade partidária, bem como analisar a constitucionalidade do dispositivo supracitado. Além disso, propõe-se uma breve análise de como as mudanças legislativas e jurisprudenciais no Direito Eleitoral refletem em torno do tema. Nesse contexto, busca-se discutir se a migração para legenda nova se configura justa causa para a infidelidade partidária. Para tanto, abordam-se as temáticas relacionadas a esse assunto, como o pluralismo político e o sistema eleitoral proporcional. Por fim, a ideia é aproximar de 
uma conclusão razoável sobre a constitucionalidade ou não de se permitir a infidelidade partidária quando um novo partido é criado e o político deseja se transferir para essa nova legenda.

Apesar de o mérito da ADI n 5.398 não ter chegado ao plenário do STF, tem-se que ainda não ocorreu, no cenário político brasileiro atual, um caso em que um parlamentar tenha se transferido para uma legenda recém-criada. Isso porque, até o momento, os últimos partidos que conseguiram finalizar o processo de criação acabaram por ser abarcados pela medida cautelar deferida pelo ministro-relator Roberto Barroso. Como a sanção da Lei $n^{\circ}$ 13.165/2015 se deu em 29 de setembro de 2015, foram beneficiados, pela decisão liminar, além do autor da ação, a Rede Sustentabilidade, o Partido Novo, cujo registro data de 15 de setembro de 2015, e o PMB, Partido da Mulher Brasileira, com registro em 29 de setembro de 2015. Dessa forma, percebe-se uma incógnita em relação ao que irá ocorrer caso novos partidos consigam obter o registro final junto ao TSE.

\section{Pluralismo político e representação}

No Brasil, o Direito Eleitoral, conforme conceituação de Omar Chamon, "é ramo autônomo, que se dedica ao estudo das normas e procedimentos que organizam e disciplinam o funcionamento do poder de sufrágio popular, de modo que se estabeleça a precisa equação entre a vontade do povo e a atividade governamental.’'(2006, p. 21). Nesse sentido, a doutrina, a jurisprudência e a legislação desse ramo nos fornecem subsídios sistemáticos para a análise da conformidade constitucional quando uma novidade legislativa se apresenta.

A opção pela adoção de um governo representativo está expressa no parágrafo único do art. $1^{\circ}$ da Constituição da República, em que está disposto que todo o poder emana do povo, que o exerce por meio de representantes eleitos ou diretamente, nos termos da Constituição. Assim, também há destaque para o pluralismo político, fundamento da República Federativa do Brasil, conforme o mesmo artigo supracitado. Segundo a doutrina, o pluralismo político relaciona-se à diversidade de ideias, de grupos, de setores, organizados ou não, que sejam formadores de opinião da sociedade brasileira (JORGE; LIBERATO; RODRIGUES; 2016, p. 52).

Alexandre de Moraes é outro a destacar que o pluralismo político "demonstra preocupação do legislador constituinte em afirmar a ampla e 
livre participação popular nos destinos do país, garantindo-se a liberdade de convicção filosófica e política e, também, a possibilidade de organização e participação em partidos políticos" (MORAES, 2005, p. 131). Por sua vez, a relação entre o princípio do pluralismo político e o pluripartidarismo é demonstrada por Fávila Ribeiro: "o pluralismo político encontra no sistema pluripartidarista um de seus eficientes instrumentos nos múltiplos papéis que empreende (...) sortimentos de ideias, sentimentos, impressões e interesses (...)" (RIBEIRO, 1998, p. 211).

Sobre o governo representativo, têm-se as considerações de John Stuart Mill (1981, p. 38), cujo conceito clássico aponta na direção de que a representação é caminho fundamental para a democracia, vez que estamos diante da impossibilidade da participação direta do cidadão nos rumos políticos de um país. Percebe-se que, ao longo dos anos, um sistema alternativo a esse ainda não se apresentou viável nas democracias modernas.

(...) toma-se evidente que o único governo capaz de satisfazer a todas as exigências do estado social é aquele do qual participou o povo inteiro; que toda a participação, por menor que seja, é útil; que a participação deverá ser, em toda parte, na proporção em que permitir o grau geral de desenvolvimento da comunidade; e que não se pode desejar nada menor do que a admissão de todos a uma parte do poder soberano do Estado. Mas como, nas comunidades que excedem as proporções de um pequeno vilarejo, é impossível a participação pessoal de todos, a não ser numa porção muito pequena dos negócios públicos, o tipo ideal de um governo perfeito só pode ser o representativo. (MILL, 1981, p. 38)

A candidatura de qualquer cidadão a cargo eletivo depende de prévia filiação partidária, de acordo com exigência constitucional ${ }^{1}$ e também por força do o Código Eleitoral². Portanto, os partidos políticos obtiveram, no contexto brasileiro, protagonismo na democracia representativa, não sendo admitida, portanto, a candidatura individual a cargo eletivo sem a filiação a partido político devidamente constituído. A vedação à candidatura

\footnotetext{
${ }^{1}$ Art. 14. A soberania popular será exercida pelo sufrágio universal e pelo voto direto e secreto, com valor igual para todos, e, nos termos da lei, mediante:

$\int 3^{\circ}$ São condições de elegibilidade, na forma da lei:

V - a filiação partidária; (BRASIL, 1988)

${ }^{2}$ Art. 16. Só pode filiar-se a partido o eleitor que estiver no pleno gozo de seus direitos políticos. (BRASIL, 1995)
} 
avulsa ganhou status constitucional pela primeira vez no país na Constituição da República de 1946, sendo que a consequência dessa vedação é a indispensabilidade dos partidos políticos nas disputas eleitorais.

Somente candidatos filiados há pelo menos seis meses $^{3}$, a partidos políticos devidamente inscritos no TSE podem ter suas candidaturas registradas para a eleição a ser realizada. Por sua vez, o art. $17, \sqrt{ } 1^{\circ}$ dispõe que os partidos políticos podem estabelecer normas de fidelidade e disciplina. A norma constitucional ainda consagra a liberdade de criação e a autonomia dos partidos políticos para definir sua estrutura interna, sua organização e seu funcionamento (Brasil, 1988).

No contexto do sistema representativo brasileiro, nas eleições para os cargos do legislativo, exceto para o de senador, vigora o método proporcional de apuração dos eleitos, muito incentivado pela necessidade de se assegurar a representação de variadas correntes ideológicas, além de ser ferramenta de valorização do pluralismo político (art. 1ํ, V, CR). O conceito de pluralismo, na visão de Bobbio (1999), permitiria um sistema político aberto à participação de vários grupos ou camadas sociais na formação da vontade coletiva.

(...) o pluralismo evoca, positivamente, um estado de coisas no qual não existe um poder monolítico e no qual, havendo muitos centros de poder bem distribuídos territorial e funcionalmente, o indivíduo tem a máxima possibilidade de participar na formação das deliberações que lhe dizem respeito. (BOBBIO, 1999, p. 22).

Assis Brasil (1931, p. 113) afirma que a representação é nacional e não de um partido e, dessa forma, deve refletir a soma das opiniões de todo o povo. Já na visão de Pinto Ferreira (1983, p. 226), a representação expressaria situação política e jurídica em que determinados indivíduos exercem funções estatais em nome do povo.

$\mathrm{Na}$ democracia representativa, segundo José Afonso da Silva (2009, p. 41), a participação popular ocorreria de maneira indireta, periódica e formal, dentro de um procedimento técnico de designação de pessoas para o exercício de funções governamentais, além de demostrar, por meio

\footnotetext{
${ }^{3}$ Art. 9o Para concorrer às eleições, o candidato deverá possuir domicílio eleitoral na respectiva circunscrição pelo prazo de seis meses e estar com a filiação deferida pelo partido no mesmo prazo. (BRASIL, 2017)
}

Resenha Eleitoral (Florianópolis), v. 22, n. 1-2, p. 163-188, 2018 
do voto, a preferência entre alternativas ideológicas. Jairo Nicolau, por seu turno, esclarece que sistema eleitoral é “(...) o conjunto de regras que define como em uma determinada eleição o eleitor pode fazer suas escolhas e como os votos são contabilizados para serem transformados em mandatos (cadeiras no Legislativo ou chefia do Executivo) (NICOLAU, 2004, p. 10). No bojo do sistema representativo, temos a opção entre os sistemas eleitorais, o proporcional ou o majoritário. No majoritário, como o nome diz, ganha o pleito quem tem mais votos.

\section{O sistema proporcional brasileiro}

A Constituição da República definiu que as eleições dos deputados federais, dos deputados estaduais e dos vereadores adotarão o critério proporcional (arts. 27, \1ㅇ, e 45) ${ }^{4}$. Esse sistema visa assegurar que "a diversidade de opiniões esteja refletida no legislativo e garantir uma correspondência entre os votos recebidos pelos partidos e sua representação" (NICOLAU, 2004, p. 37). Cabe destacar que o sistema proporcional não tem o condão de assegurar a representação das minorias, mas sim de dar espaço àquelas opiniões que, existindo em força numérica, têm o direito de influir no governo do país. Dessa forma, é notável que a opção brasileira passa por garantir espaço de expressão política das mais diversas ideologias, cujos entendimentos e objetivos são agrupados em programas partidários. Conforme Canotilho (1998, p. 308), os partidos políticos são “organizações aglutinadoras dos interesses e mundividência de certas classes e grupos sociais impulsionadores da formação da vontade popular".

No mesmo entendimento, Almeida (2017, p. 179) apresenta o conceito de partido político, no qual um grupo de indivíduos se associa, de forma estável, em torno de um objetivo determinado, que é assumir e permanecer no poder ou, pelo menos, influenciar suas decisões, de modo a colocar em prática determinada ideologia político-administrativa. Os partidos políticos, portanto, segundo Almeida (2017, p. 183), denotam autenticidade

\footnotetext{
${ }^{4}$ Art. 27. O número de Deputados à Assembleia Legislativa corresponderá ao triplo da representação do Estado na Câmara dos Deputados e, atingido o número de trinta e seis, será acrescido de tantos quantos forem os Deputados Federais acima de doze.

$\int 1^{\circ}$ Será de quatro anos o mandato dos Deputados Estaduais, aplicando-se-lhes as regras desta Constituição sobre sistema eleitoral, inviolabilidade, imunidades, remuneração, perda de mandato, licença, impedimentos e incorporação às Forças Armadas. (BRASIL, 1988)

Art. 45. A Câmara dos Deputados compõe-se de representantes do povo, eleitos, pelo sistema proporcional, em cada Estado, em cada Território e no Distrito Federal. (BRASIL, 1988)
} 
ao sistema representativo, na postulação da defesa dos direitos fundamentais presentes na Constituição da República. Do mesmo modo, Jorge, Liberato e Rodrigues (2016, p. 164) elevam o partido político a elo fundamental entre o povo e o Estado. De acordo com os autores, as legendas servem de canal de aglutinação, debate, reflexão e discussão da sociedade civil em torno de ideais políticos.

O funcionamento do sistema representativo proporcional está regulado pelo art. 106 e seguintes do Código Eleitoral, em que se estabelece que o quociente eleitoral é a divisão do número de votos válidos apurados pelo de lugares a preencher em cada circunscrição eleitoral, desprezada a fração se igual ou inferior a meio, equivalente a um, se superior. Feito o cálculo, determina-se, para cada partido ou coligação, o quociente partidário, dividindo-se pelo quociente eleitoral o número de votos válidos dados sob a mesma legenda ou coligação de legendas, desprezada a fração. Dessa forma, estarão eleitos, entre os candidatos registrados por um partido ou coligação que tenham obtido votos em número igual ou superior a $10 \%$ (dez por cento) do quociente eleitoral, tantos quantos o respectivo quociente partidário indicar, na ordem da votação nominal que cada um tenha recebido.

Segundo Nicolau (2004, p. 38), o sistema de lista procura distribuir as cadeiras do Parlamento utilizando os partidos como unidade fundamental. Por isso, são calculadas a quota de votos que cada candidato deve atingir para ser representado e a quota que cada partido deve obter. Esse modelo de sistema proporcional chamado de listas, no caso brasileiro, de lista aberta, tenderia a levar o protagonismo aos partidos e não aos candidatos. Logo, a ideia é termos a disputa entre grupos políticos.

A legislação brasileira adotou o sistema proporcional de listas abertas e votação nominal. Os eleitores podem optar por votar nominalmente em seu candidato, ou somente na legenda. Já o sistema proporcional de listas fechadas é aquele em que a relação é apresentada pelos partidos, fazendo-se a distribuição de vagas conforme a votação obtida pelo partido e pela posição atribuída ao candidato na lista partidária. Na mesma linha de raciocínio, Edson de Resende Castro (2014, p. 24) explica que "o sistema proporcional busca o desempenho partidário - e não o desempenho pessoal -, pois todos os votos são dados primeiramente no partido, e, às vezes, apenas no partido". 
Contudo, cabe salientar que o sistema de listas abertas sofre críticas doutrinárias e jurisprudenciais, uma vez que ele desvia a atenção do programa do partido, centralizando, muitas vezes, para a personalização da eleição, criando certa dependência do desempenho dos candidatos. Não é escopo deste trabalho, mas as críticas são no sentido de que o sistema de lista aberta acabou por personalizar o voto na figura do candidato, em detrimento da escolha, pelo eleitor, de uma ideologia representada por aquela legenda. "Essa personalização do voto acaba por acentuar a dependência do partido e a determinar a sua fragilidade programática" (MENDES, 2016, p. 27). Dessa forma, ainda para Mendes, "a lista aberta de candidatos existente no Brasil faz com que o mandato parlamentar, que resulta desse sistema, afigure-se também mais como fruto do desempenho e do esforço do candidato do que da atividade partidária.” (MENDES, 2016, p. 17)

Paulo Bonavides já demonstrava que o sistema eleitoral tem consequências diversas para os rumos da democracia representativa de um país. Segundo o autor, "O sistema eleitoral adotado num país pode exercer - e em verdade exerce - considerável influxo sobre a forma de governo, a organização partidária e a estrutura parlamentar, refletindo até certo ponto a índole das instituições e a orientação política do regime" (BONAVIDES, 2012, p. 265). Nesse contexto, uma das questões que se apresenta é a aplicação da fidelidade partidária, quando um novo partido é criado e parlamentar em exercício de mandato deseja, desde já, realizar a transferência a essa nova legenda.

\section{Fidelidade partidária: trajetória constitucional, legal e jurisprudencial}

A fidelidade partidária encontra aparato constitucional na parte final do $\$ 1^{\circ}$ do art. 17 da $C R$, em que se estabelece que os estatutos dos partidos políticos devem prever as normas de disciplina e fidelidade partidária ${ }^{5}$. Diante disso, a Lei nº 9096/1995 (Lei dos Partidos Políticos)

\footnotetext{
${ }^{5}$ Art. 17. É livre a criação, fusão, incorporação e extinção de partidos políticos, resguardados a soberania nacional, o regime democrático, o pluripartidarismo, os direitos fundamentais da pessoa humana e observados os seguintes preceitos:

(...)

$\int 1^{\circ} \mathrm{E}$ assegurada aos partidos políticos autonomia para definir sua estrutura interna e estabelecer regras sobre escolha, formação e duração de seus órgãos permanentes e provisórios e sobre sua organização e funcionamento e para adotar os critérios de escolha e
} 
apresentou, nos arts. 23 a 26, as normas infraconstitucionais aplicáveis à fidelidade partidária. Nesse esteio, restou determinado que a responsabilidade por violação dos deveres partidários deve ser apurada e punida pelo competente órgão, na conformidade do que disponha o estatuto de cada partido (BRASIL, 1995). Além disso, num reforço ao respeito do sistema proporcional, a lei dita que, na Casa Legislativa, o integrante da bancada de partido deve subordinar sua ação parlamentar aos princípios doutrinários e programáticos e às diretrizes estabelecidas pelos órgãos de direção partidários, na forma dos estatutos.

Apesar de prever punições aos considerados infiéis, a Lei dos Partidos não chegou a determinar possibilidade da medida mais gravosa, nesse caso, a de perda do mandato eletivo. Entretanto, permite-se, ao estatuto do partido, dispor sobre a aplicação de medidas disciplinares básicas de caráter partidário, normas sobre penalidades, inclusive com o desligamento temporário da bancada, suspensão do direito de voto nas reuniões internas ou perda de todas as prerrogativas, cargos e funções que exerça em decorrência da representação e da proporção partidária, na respectiva Casa Legislativa, ao parlamentar que se opuser, pela atitude ou pelo voto, às diretrizes legitimamente estabelecidas pelos órgãos partidários. Em relação à saída voluntária do parlamentar do partido sob cuja legenda tenha sido eleito, existia apenas a previsão da perda automaticamente da função ou cargo que exercesse na respectiva Casa Legislativa, em virtude da proporção partidária (BRASIL, 1995).

Com a ausência de previsão normativa de perda de mandato eletivo em caso de mudança de partido, o Partido da Frente Liberal (atual Democratas) abriu consulta ao Tribunal Superior Eleitoral, cujo entendimento, consubstanciado na Consulta $\mathrm{n}^{\circ}$ 1.398/2007, considerou que a mudança de agremiação de parlamentar eleito pelo sistema proporcional dá ao partido o direito de reter sua vaga. O Supremo Tribunal Federal fixou a mesma tese na análise dos Mandados de Segurança nºs 26.602, 26.603 e 26.604, em 2007. Nessas ocasiões, tanto o TSE quanto o STF já reconheceram a existência de hipóteses excepcionais em que a mudança de partido político não

o regime de suas coligações nas eleições majoritárias, vedada a sua celebração nas eleições proporcionais, sem obrigatoriedade de vinculação entre as candidaturas em âmbito nacional, estadual, distrital ou municipal, devendo seus estatutos estabelecer normas de disciplina e fidelidade partidária. (BRASIL, 1988) 
acarretaria a perda do cargo pelo parlamentar, como a mudança significativa de orientação programática do partido e de prática odiosa de perseguição ao filiado.

Cabe ressaltar que o arcabouço normativo brasileiro reúne diversos dispositivos em que fica demonstrada a afirmação de que o mandato eletivo proporcional pertence ao Partido Político. Um exemplo é o art. 175, $\int 4^{\mathrm{o}}$, do Código Eleitoral ${ }^{6}$. Esse dispositivo dá forte indicação de que os votos pertencem ao partido, uma vez que prevê a validade, para este, dos votos destinados a candidato considerado inelegível ou que tenha o registro cancelado. Outro indicativo dessa situação é o fato de a eleição dos candidatos a cargos proporcionais ser o resultado do quociente eleitoral apurado entre os diversos partidos envolvidos, conforme o art. 108, caput, do Código Eleitoral ${ }^{7}$. Todas essas situações foram possíveis já que o eleitor pode dirigir seu voto à agremiação partidária e não somente ao candidato, na figura do voto de legenda, conforme o art. 5², da Lei das Eleições (BRASIL, 1997).

A doutrina, da mesma forma, atua na defesa de que a fidelidade partidária é um instituto a ser protegido. Em nome do fortalecimento da figura da representação popular por via indireta, "é preciso que os mandatários se mantenham fiéis às diretrizes programáticas e ideológicas dos partidos pelos quais foram eleitos" (LEWANDOWSKI, 2010, p. 11). De acordo com Telles Júnior, "sem fidelidade dos parlamentares aos ideários de interesse coletivo (...) definidos nos respectivos programas registrados, os partidos se reduzem a estratagemas indignos, a serviço de egoísmos disfarçados; e os políticos se desmoralizam.” (TELLES JÚNIOR, 2005, p. 117)

\footnotetext{
${ }^{6}$ Art. 175. Serão nulas as cédulas:

(...)

$\int 3^{\text {o }}$ Serão nulos, para todos os efeitos, os votos dados a candidatos inelegíveis ou não registrados.

$\int 4^{\circ} \mathrm{O}$ disposto no parágrafo anterior não se aplica quando a decisão de inelegibilidade ou de cancelamento de registro for proferida após a realização da eleição a que concorreu o candidato alcançado pela sentença, caso em que os votos serão contados para o partido pelo qual tiver sido feito o seu registro. (BRASIL, 1965)

${ }^{7}$ Art. 108. Estarão eleitos, entre os candidatos registrados por um partido ou coligação que tenham obtido votos em número igual ou superior a $10 \%$ (dez por cento) do quociente eleitoral, tantos quantos o respectivo quociente partidário indicar, na ordem da votação nominal que cada um tenha recebido. (BRASIL, 1965)
} 
Por determinação do STF, a regulamentação do procedimento em caso de mudança de partido coube ao TSE, que o fez com a edição da Resolução n⿳o 22.610/2007, de 25 de outubro de 2007. A normativa disciplinou o processo de perda de cargo eletivo, bem como de justificação de desfiliação partidária, e estabeleceu como hipóteses de justa causa: I) incorporação ou fusão do partido; II) criação de novo partido; III) mudança substancial ou desvio reiterado do programa partidário; IV) grave discriminação pessoal. Vale ressaltar que a resolução não fixou o prazo em que o partido ainda é considerado novo, no entanto, em sede de jurisprudência, a Justiça Eleitoral propugnou que o parlamentar teria trinta dias para realizar a transferência a partir do momento em que a nova legenda realizasse o registro do seu estatuto pelo TSE. Posteriormente, em junho de 2011, o TSE definiu, na Consulta $n^{\circ}$ 755-35, que o prazo razoável para a filiação no novo partido, com amparo na justa causa prevista na Resolução no $22.610 / 2007$, seria de 30 dias, contados do registro do estatuto partidário pelo TSE.

Desse modo, para aqueles que contribuíram para criação do partido, é razoável aplicar analogicamente o prazo de 30 dias, previsto no art. 9, $\sqrt{4}$, da Lei n. ${ }^{\circ}$ 9.096/95, a contar da data do registro do estatuto pelo TSE. Assim, o prazo razoável para filiação no novo partido é de 30 dias, contados do registro do estatuto partidário pelo TSE. (TSE, CTA 75535/DF, Rel. Min. Fátima Nancy Andrighi, DJE 01.08.11)

Em novembro de 2008, a constitucionalidade formal da Resolução foi confirmada pelo STF no julgamento das ADIs no 3.999 e n⿳ 4.086, com o afastamento da tese da ocorrência de usurpação de competência legislativa. Ainda como consequência do reconhecimento da criação de novo partido como causa legitimadora da desfiliação partidária, o STF, ao apreciar as ADIs no 4.430 e $n^{\circ}$ 4.795, assentou a inconstitucionalidade de impedir que partidos novos aproveitassem a representatividade dos deputados federais que tenham para eles migrado, para fins de acesso proporcional ao direito de antena e aos recursos do fundo partidário.

Consolidou-se, assim, um regime em que as novas legendas tinham a possibilidade de receber em seus quadros, nos 30 dias subsequentes ao registro de seu estatuto no TSE, filiados detentores de mandatos eletivos, de modo a permitir o seu desenvolvimento com a obtenção de funcionamento parlamentar, maior tempo de propaganda eleitoral na TV e no rádio, e maior fração de recursos públicos do fundo partidário. 
A Resolução do TSE n⿳0 22.610/2007 perderia validade com a aprovação e a sanção da Lei no 13.165, de 29 de setembro de 2015, apelidada de minirreforma eleitoral. O art. 22-A ${ }^{8}$, incluído na Lei no 9.096/1995, apresentou rol taxativo para as hipóteses de justa causa de desfiliação partidária. Contudo, esse novo rol não incluiu a criação de novo partido. No entanto, permitiu a "mudança de partido efetuada durante o período de trinta dias que antecede o prazo de filiação exigido em lei para concorrer à eleição, majoritária ou proporcional, ao término do mandato vigente" (BRASIL, 2015). Dessa forma, manteve-se a possibilidade de migração a novos partidos ou a qualquer outra legenda, sem perda do cargo pelo parlamentar migrante. Assim, um partido recém-criado só poderá receber parlamentares quando se abrir a janela, sete meses antes das eleições proporcionais.

Diante disso, em 2015, o partido político Rede Sustentabilidade propôs ação direta de inconstitucionalidade (ADI $\mathrm{n}^{\mathrm{o}}$ 5.398), com pedido de medida cautelar, tendo por escopo o artigo 22-A da Lei n 9.096/1995, introduzido pela Lei n 13.165/2015. O objeto da ação é a declaração da inconstitucionalidade parcial, sem redução de texto, de referida norma na parte em que não considera justa causa para desfiliação partidária à criação de novo partido político. A Rede Sustentabilidade argumenta que, até a edição da Lei n 13.165, em 29 de setembro de 2015, havia um regime jurídico consolidado, nos termos da Resolução TSE n⿳ 22.610/2007, o qual previa que a criação de novos partidos constituía justa causa para a desfiliação partidária.

A ADI n 5.398 teve medida cautelar deferida parcialmente, a ser referendada pelo Plenário do Supremo Tribunal Federal, para restabelecer o prazo integral de 30 dias a fim de que detentores de mandatos eletivos se filiassem aos novos partidos registrados no Tribunal Superior Eleitoral (TSE), imediatamente antes da entrada em vigor da Lei n 13.165/2015. Os

\footnotetext{
${ }^{8}$ Art. 22-A. Perderá o mandato o detentor de cargo eletivo que se desfiliar, sem justa causa, do partido pelo qual foi eleito. (Incluído pela Lei n 13.165 , de 2015)

Parágrafo único. Consideram-se justa causa para a desfiliação partidária somente as seguintes hipóteses: (Incluído pela Lei n⿳⼈ㅜ 13.165, de 2015)

I - mudança substancial ou desvio reiterado do programa partidário; (Incluído pela Lei no 13.165, de 2015)

II - grave discriminação política pessoal; e (Incluído pela Lei no 13.165, de 2015)

III - mudança de partido efetuada durante o período de trinta dias que antecede o prazo de filiação exigido em lei para concorrer à eleição, majoritária ou proporcional, ao término do mandato vigente. (Incluído pela Lei no 13.165 , de 2015) (BRASIL, 2015)
} 
autos ADI estão conclusos ao ministro relator Roberto Barroso desde 26 de novembro de 2015, portanto, a medida cautelar e tão pouco o mérito da ação chegaram à apreciação do plenário do STF.

\section{Da constitucionalidade da migração para legenda recém-criada}

Apesar de o mérito da ADI no 5.398 não ter chegado ao plenário do STF, tem-se que ainda não ocorreu, no cenário político brasileiro atual, um caso em que um parlamentar tenha se transferido a uma legenda recém-criada. Isso porque, até o momento, os últimos partidos que conseguiram finalizar o processo de criação acabaram por ser abarcados pela medida cautelar deferida pele ministro-relator Roberto Barroso. Como a sanção da Lei no 13.165/2015 se deu em 29 de setembro de 2015, foram beneficiados pela decisão liminar, além do autor da ação, o Partido Novo, cujo registro data de 15 de setembro de 2015, e o PMB, Partido da Mulher Brasileira, com registro em 29 de setembro de 2015. Dessa forma, percebe-se uma incógnita em relação ao que irá ocorrer caso novos partidos consigam obter o registro final junto ao TSE.

O Brasil conta hoje com 35 partidos políticos registrados no TSE. Para apresentar o pedido de registro, as agremiações em formação têm de cumprir os requisitos da Resolução TSE n⿳o 23.465/2015 e da Lei dos Partidos Políticos (Lei no 9.096/1995), com as alterações promovidas pela Lei n⿳o 13.165/2015. A nova lei modificou o parágrafo $1^{\circ}$, artigo $7^{\circ}$, da Lei dos Partidos Políticos, ao definir um prazo de dois anos para se comprovar o apoiamento de eleitores não filiados para a criação de novas agremiações. A regra dificulta a criação de partidos, contudo já foi referendada pelo Supremo Tribunal Federal no julgamento da ADI no 5311.

EMENTA: AÇÃO DIRETA DE INCONSTITUCIONALIDADE. LEI NACIONAL N. 13.107, DE 24 DE MARÇO DE 2015. ALTERAÇÃO DA LEI DOS PARTIDOS POLÍTICOS E DA LEI ELEITORAL (LEI 9.096/1995 E 9.504/1997). NOVAS CONDIÇÕES LEGAIS PARA CRIAÇÃO, FUSÃO E INCORPORAÇÃO DE PARTIDOS POLÍTICOS. APOIO DE ELEITORES NÃO FILIADOS E PRAZO MÍNIMO DE CINCO ANOS DE EXISTÊNCIA DOS PARTIDOS. FORTALECIMENTO DO MODELO REPRESENTATIVO E DENSIFICAÇÃO DO PLU- 
RIPARTIDARISMO. FUNDAMENTO DO PRINCÍPIO DEMOCRÁTICO. FIDELIDADE PARTIDÁRIA. INDEFERIMENTO DA CAUTELAR. 1. A Constituição da República assegura a livre criação, fusão e incorporação de partidos políticos. Liberdade não é absoluta, condicionando-se aos princípios do sistema democrático-representativo e do pluripartidarismo. 2. São constitucionais as normas que fortalecem o controle quantitativo e qualitativo dos partidos, sem afronta ao princípio da igualdade ou qualquer ingerência em seu funcionamento interno. 3. O requisito constitucional do caráter nacional dos partidos políticos objetiva impedir a proliferação de agremiações sem expressão política, que podem atuar como "legendas de aluguel", fraudando a representação, base do regime democrático. 4. Medida cautelar indeferida. (ADI 5311 MC, Relator(a): Min. CÁRMEN LÚCIA, Tribunal Pleno, julgado em 30/09/2015, PROCESSO ELETRÔNICO DJe-021 DIVULG 03-02-2016 PUBLIC 04-02-2016)

Cabe ressaltar que, no julgado, evidente inclinação à crítica de que a proliferação de partidos na democracia representativa brasileira leva ao enfraquecimento do modelo, conforme já apontava Paulo Bonavides em 1996: "Tamanha afirmação e alargamento de pluralismo estaria, pois, comprometendo e sacrificando a eficácia governante do princípio representativo e ao mesmo passo contestando-lhe as virtudes operativas apregoadas." (BONAVIDES, 1996, p. 37). Nesse sentido, a relatora da ADI no 5311, a ministra Cármen Lúcia, fez uma alerta: "a proliferação indiscriminada de partidos sem coerência ou respaldo social importa em risco institucional, podendo conduzir ao desalento democrático, perigoso precursor de regimes antidemocráticos."

Até o momento, há 69 legendas em processo de formação9 . O primeiro passo para que uma legenda obtenha seu registro é dirigir o requerimento ao cartório competente do Registro Civil das Pessoas Jurídicas da Capital Federal. O pedido deve ser subscrito pelos seus fundadores, em número nunca inferior a 101, com domicílio eleitoral em, no mínimo, 1/3 dos estados.

Depois de cumpridas tais exigências, além dos requisitos estabelecidos na Lei de Registros Públicos, o oficial do Registro Civil efetuará o re-

\footnotetext{
${ }_{9}^{9}$ Disponível em: < http://www.tse.jus.br/partidos/partidos-politicos/criacao-de-partido/ partidos-em-formacao >. Acesso em: $11 \mathrm{dez} .2017$.
} 
gistro no livro correspondente, expedindo certidão de inteiro teor. A partir daí, segundo o parágrafo 3o do artigo 10 da Resolução n⿳0 23.465, a legenda em formação terá 100 dias para informar o TSE sobre a sua criação.

Depois de adquirida a personalidade jurídica, a agremiação partidária em formação promoverá a obtenção do apoiamento mínimo de eleitores não filiados a outros partidos políticos, o que deverá ser comprovado no prazo de dois anos.

De acordo com o parágrafo $2^{\circ}$ do artigo $7^{\circ}$ da Resolução n 23.465, o apoiamento mínimo deve corresponder a, pelo menos, $0,5 \%$ (meio por cento) dos votos dados na última eleição geral para a Câmara dos Deputados (aproximadamente 500 mil), não computados os votos em branco e os nulos, distribuídos por um terço, ou mais, dos estados, com um mínimo de $0,1 \%$ do eleitorado que haja votado em cada um deles.

O apoiamento mínimo deve ser obtido mediante assinaturas de eleitores - não filiados a partidos políticos - em listas ou formulários de acordo com os modelos disponibilizados pela Justiça Eleitoral. O requerimento de registro de partido político somente deverá ser dirigido ao TSE depois de registrados os órgãos de direção regional em, pelo menos, 1/3 dos estados. Desde o dia 20 de dezembro de 2016, todos os pedidos de registro de partido político (RPP) devem ser feitos via Processo Judicial Eletrônico (PJe).

O pedido, apresentado pelo presidente da legenda em formação, deve estar acompanhado de: cópia da ata da reunião de fundação do partido autenticada por tabelião de notas, exemplar autenticado do inteiro teor do programa e do estatuto inscritos no cartório competente do Registro Civil das Pessoas Jurídicas da Capital Federal, e relação de todos os fundadores, com nome completo, naturalidade, número do título com a zona, a seção, o município e a unidade da Federação, bem como profissão e endereço da residência.

O requerimento também deve conter: certidão do Cartório do Registro Civil das Pessoas Jurídicas, certidões expedidas pelos Tribunais Regionais Eleitorais (TREs) que comprovem ter a legenda em formação obtido o registro do órgão de direção nos respectivos estados, e cópia da ata da reunião que comprove a constituição definitiva do órgão de direção nacional, com a designação de seus dirigentes autenticada por tabelião de notas. 
Além disso, as certidões comprobatórias do apoiamento mínimo e do deferimento do registro do órgão de direção, nos respectivos estados, deverão ser impressas e juntadas aos autos pelo TSE, sendo dispensada a sua apresentação pelo partido em formação. Depois de autuado e distribuído, a Secretaria do Tribunal deve publicar, imediatamente, no Diário da Justiça Eletrônico, edital para ciência dos interessados, segundo previsão do artigo 9ํㅜ parágrafo 3ำ da Lei nº 9.096/1995.

Percebe-se que as regras para criação de novas legendas impuseram uma série de etapas a serem cumpridas para, finalmente, concretizar-se a criação de um partido político. Vencido esse processo, indaga-se como a jurisprudência irá se comportar em relação à fidelidade partidária nos casos de transferência a partido recém-criado. Para isso, a presente pesquisa irá aprofundar-se também na análise de decisões, de modo a apontar o entendimento mais recente do Supremo Tribunal Federal em relação à fidelidade partidária, bem como à interpretação constitucional sobre o sistema representativo brasileiro.

Como já citada, a ação direta de inconstitucionalidade 5.398 DF, proposta pelo partido político Rede Sustentabilidade, visa afastar a aplicabilidade do artigo 22-A da Lei no 9.096/1995 (Lei dos Partidos Políticos), introduzido pela Lei no 13.165, de 29 de setembro de 2015 (minirreforma eleitoral de 2015). Admitida parcialmente a medida cautelar, o ministro-relator Roberto Barroso ateve-se, principalmente, à análise do direito adquirido daqueles partidos novos com registro finalizado no TSE no momento da sanção da lei. Nesse sentido, permitiu a essas legendas receber parlamentares em exercício de mandato durante o período de 30 (trinta) dias contados do registro do estatuto partidário pelo TSE, sem restar configurada a perda de mandato por infidelidade partidária. Na redação legislativa atual, o Poder Legislativo criou uma "janela” para desfiliação partidária aplicável a todos os detentores de cargo eletivo - sem distinguir se migrarão para partido novo ou preexistente -, que será aberta a cada pleito durante o período de 30 dias que antecede o prazo de filiação. O ministro-relator destacou a importância da controvérsia, no entanto, não vislumbrou nela os requisitos para a concessão de medida cautelar em relação à garantia do parlamentar proceder à mudança a partido novo a qualquer tempo.

(...) evidencia-se que a primeira controvérsia - a constitucionalidade da exclusão da criação de novo partido político como justa causa para desfiliação - possui grande complexidade e relevância constitu- 
cional. Para sua resolução, é preciso analisar se a norma impugnada nesta ADI representa um efetivo embaraço à livre criação de partidos políticos e se é ou não fruto de legítimo exercício de diálogo institucional com o STF na matéria. Contudo, entendo que não há perigo de demora que justifique a sua apreciação em juízo de cognição sumária típico das cautelares. (BARROSO, Roberto. 2015)

Ocorre que, como o mérito do $\mathrm{ADI} \mathrm{n}^{\circ} 5.398 \mathrm{DF}$ não chegou à análise final pelo plenário do STF, percebe-se que, quando uma nova agremiação partidária lograr sucesso em se registrar no TSE, paira incerteza se haverá permissão para o recebimento de parlamentares em exercício de mandato, medida que tem impactos no recebimento de parcela do fundo partidário e tempo de propaganda eleitoral, conforme decisão do próprio STF na ADI no 4.430.

Importante ressaltar que a $\mathrm{ADI} \mathrm{n}^{\circ} 4.430$ propugnou pela liberdade de criação partidária e, portanto, pela permissão de mudança do parlamentar para partido recém-criado, pois, segundo, o ministro-relator Dias Toffoli, tal "interpretação prestigia, por um lado, a liberdade constitucional de criação de partidos (art. 17, caput, CF/88) e, por outro, a representatividade do partido que já nasce com representantes parlamentares, tudo em consonância com o sistema de representação proporcional brasileiro.”

EMENTA: Ações diretas de inconstitucionalidade. Julgamento conjunto da ADI $\mathrm{n}^{\circ} 4.430$ e da ADI no 4.795. Artigo 45, \ 6o, e art. 47, incisos I e II, da Lei no 9.504/97 (Lei das Eleições). (...) Criação de novos partidos políticos e as alterações de representatividade na Câmara dos Deputados. Acesso das novas legendas ao rádio e à TV proporcionalmente ao número de representantes na Câmara dos Deputados (inciso II do $\ 2^{2}$ do art. 47 da Lei no 9.504/97), considerada a representação dos deputados federais que tenham migrado diretamente dos partidos pelos quais foram eleitos para a nova legenda no momento de sua criação. Momento de aferição do número de representantes na Câmara Federal. Não aplicação do $\ 3^{\circ}$ do art. 47 da Lei 9.504/97, segundo o qual, a representação de cada partido na Câmara Federal é a resultante da última eleição para deputados federais. Critério inaplicável aos novos partidos. Liberdade de criação, fusão e incorporação de partidos políticos (art. 17, caput, CF/88). Equiparação constitucional. Interpretação conforme. (...) 
6. Extrai-se do princípio da liberdade de criação e transformação de partidos políticos contido no caput do art. 17 da Constituição da República o fundamento constitucional para reputar como legítimo o entendimento de que, na hipótese de criação de um novo partido, a novel legenda, para fins de acesso proporcional ao rádio e à televisão, leva consigo a representatividade dos deputados federais que, quando de sua criação, para ela migrarem diretamente dos partidos pelos quais foram eleitos. Não há razão para se conferir às hipóteses de criação de nova legenda, tratamento diverso daquele conferido aos casos de fusão e incorporação de partidos (art. 47, \ 4º Lei das Eleições), já que todas essas hipóteses detêm o mesmo patamar constitucional (art. 17, caput, CF/88), cabendo à lei, e também ao seu intérprete, preservar o sistema. Se se entende que a criação de partido político autoriza a migração dos parlamentares para a novel legenda, sem que se possa falar em infidelidade partidária ou em perda do mandato parlamentar, essa mudança resulta, de igual forma, na alteração da representação política da legenda originária. Note-se que a Lei das Eleições, ao adotar o marco da última eleição para deputados federais para fins de verificação da representação do partido (art. 47, \ 3ㅜ da Lei 9.504/97), não considerou a hipótese de criação de nova legenda. Nesse caso, o que deve prevalecer não é o desempenho do partido nas eleições (critério inaplicável aos novos partidos), mas, sim, a representatividade política conferida aos parlamentares que deixaram seus partidos de origem para se filiarem ao novo partido político, recém criado. Essa interpretação prestigia, por um lado, a liberdade constitucional de criação de partidos políticos (art. 17, caput, CF/88) e, por outro, a representatividade do partido que já nasce com representantes parlamentares, tudo em consonância com o sistema de representação proporcional brasileiro.(...) (ADI 4430, Relator(a): Min. DIAS TOFFOLI, Tribunal Pleno, julgado em 29/06/2012, PROCESSO ELETRÔNICO DJe-184 DIVULG 1809-2013 PUBLIC 19-09-2013 RTJ VOL-00226-01 PP-00257)

Ainda sobre esse julgamento, o ministro-relator Dias Toffoli afirmou que é defeso "à legislação instituir mecanismos que, na prática, excluam das legendas menores a possibilidade de crescimento e de consolidação no contexto eleitoral" (ADI no 4430 DF).

Por outro lado, o Supremo Tribunal Federal deu indícios de que pode haver mudança no entendimento tradicional da corte, uma vez que alguns ministros já apontam que o posicionamento anterior demonstrou 
efeitos colaterais negativos na permissão à transferência de parlamentar à nova legenda. As principais críticas apresentam-se no julgamento do pleno da medida cautelar na ADI no $5.311 \mathrm{MC} / \mathrm{DF}$, cuja relatoria é da ministra Cármen Lúcia. A ação direta de inconstitucionalidade, proposta pelo Partido Republicano da Ordem Social (PROS), pretende a suspensão de dois dispositivos da Lei no 9.096/1995 (Lei dos Partidos Políticos). O primeiro deles é o que impede a contabilização, para fins de criação de partidos políticos, de assinatura de eleitores filiados a outras legendas; e outro é o que veda a fusão ou a incorporação de partidos com menos de cinco anos. A decisão foi tomada por maioria de votos na sessão de 30 de setembro de 2015. Conforme entendimento da ministra-relatora, é importante o pronunciamento do STF nesse caso, pois, segundo ela, versaria sobre os mecanismos e instrumentos de legitimação do exercício do poder político no Brasil. Entretanto, o mérito não chegou ao pleno.

EMENTA: AÇÃO DIRETA DE INCONSTITUCIONALIDADE. LEI NACIONAL N. 13.107, DE 24 DE MARÇO DE 2015. ALTERAÇÃO DA LEI DOS PARTIDOS POLÍTICOS E DA LEI ELEITORAL (LEI 9.096/1995 E 9.504/1997). NOVAS CONDIÇÕES LEGAIS PARA CRIAÇÃO, FUSÃO E INCORPORAÇÃO DE PARTIDOS POLÍTICOS. APOIO DE ELEITORES NÃO FILIADOS E PRAZO MÍNIMO DE CINCO ANOS DE EXISTÊNCIA DOS PATIDOS. FORTALECIMENTO DO MODELO REPRESENTATIVO E DENSIFICAÇÃO DO PLURIPARTIDARISMO. FUNDAMENTO DO PRINCÍPIO DEMOCRÁTICO. FIDELIDADE PARTIDÁRIA. INDEFERIMENTO DA CAUTELAR. 1. A Constituição da República assegura a livre criação, fusão e incorporação de partidos políticos. Liberdade não é absoluta, condicionando-se aos princípios do sistema democrático-representativo e do pluripartidarismo. 2. São constitucionais as normas que fortalecem o controle quantitativo e qualitativo dos partidos, sem afronta ao princípio da igualdade ou qualquer ingerência em seu funcionamento interno. 3. O requisito constitucional do caráter nacional dos partidos políticos objetiva impedir a proliferação de agremiações sem expressão política, que podem atuar como "legendas de aluguel", fraudando a representação, base do regime democrático. 4. Medida cautelar indeferida. (ADI 5311 MC, Relator(a): Min. CÁRMEN LÚCIA, Tribunal Pleno, julgado em 30/09/2015, PROCESSO ELETRÔNICO DJe-021 DIVULG 03-02-2016 PUBLIC 04-02-2016) 
Para o partido, seriam inconstitucionais regras inseridas na Lei dos Partidos Políticos pela Lei no ${ }^{-13.107 / 2015}$. O primeiro trecho impugnado diz: "considerando-se como tal aquele que comprove o apoiamento de eleitores não filiados a partido político"10 e o segundo prevê tempo mínimo de cinco anos de existência do partido, com registro definitivo do Tribunal Superior Eleitoral (TSE), para a admissão de fusão ou as incorporações de legendas ${ }^{11}$.

Segundo o PROS, as modificações afrontariam diversos preceitos constitucionais ao restringir valores como pluralidade, liberdade, autonomia política e a participação do cidadão no processo político-partidário do País. Para o partido, ao limitar os eleitores que podem apoiar a criação de partidos, a norma cria diferenças entre cidadãos filiados e não filiados. Quanto ao prazo para fusão e incorporação, o partido sustenta que o artigo 17 da Constituição da República assegura a liberdade para fusão e criação de partidos. Por isso, o partido argumenta no sentido de que o tempo de cinco anos previstos na lei suprimiria essa garantia.

O entendimento da ministra-relatora, Cármen Lúcia, fundamentou-se, principalmente, na imperatividade do caráter nacional das agremiações, a partir do controle quantitativo tido como cláusula de barreira lato sensu, além do cunho democrático de seus programas, por meio do controle qualitativo ou ideológico. De acordo com ela, "ao estabelecer novas condições para a criação, fusão e incorporação de partidos políticos, as normas eleitorais definiram discrímens a serem analisadas sob o parâmetro da legitimidade representativa, fundamento do modelo partidário". Ainda na ADI $\mathrm{n}^{\circ}$ 5311, o Ministro Edson Fachin alinhou-se ao entendimento da relatora

${ }^{10}$ Art. $7^{\circ} \mathrm{O}$ partido político, após adquirir personalidade jurídica na forma da lei civil, registra seu estatuto no Tribunal Superior Eleitoral.

$\int 1^{\circ}$ Só é admitido o registro do estatuto de partido político que tenha caráter nacional, considerando-se como tal aquele que comprove, no período de dois anos, o apoiamento de eleitores não filiados a partido político, correspondente a, pelo menos, $0,5 \%$ (cinco décimos por cento) dos votos dados na última eleição geral para a Câmara dos Deputados, não computados os votos em branco e os nulos, distribuídos por um terço, ou mais, dos Estados, com um mínimo de 0,1\% (um décimo por cento) do eleitorado que haja votado em cada um deles. (BRASIL, 2015).

${ }^{11}$ Art. 29. Por decisão de seus órgãos nacionais de deliberação, dois ou mais partidos poderão fundir-se num só ou incorporar-se um ao outro.

(...)

$\int 9^{\circ}$ Somente será admitida a fusão ou incorporação de partidos políticos que hajam obtido o registro definitivo do Tribunal Superior Eleitoral há, pelo menos, 5 (cinco) anos. (BRASIL, 2015). 
e destacou que a ausência de regras que inibam a criação de partidos não ajudou a fortalecer a democracia brasileira.

Apesar de pendente a análise de mérito da criação de novo partido como justa causa para a infidelidade partidária na ADI n 5380 , Roberto

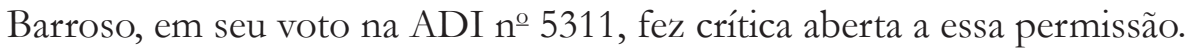

É que, quando o Supremo decidiu que a desfiliação partidária acarretava a perda de mandato, abriu-se uma exceção prevista na Resolução $\mathrm{n}^{\circ}$ 22.610/2007 do TSE: quem mudar de partido para integrar um partido novo que esteja sendo criado, não perde o mandato. Isso funcionou como um incentivo a mais à criação de partidos políticos, de tal forma que, desde a decisão do Supremo, seguida da resolução do TSE, ambas de 2007, já foram criados 8 (oito) novos partidos políticos: o Partido Social Democrático - PSD, o Partido Pátria Livre - PPL, o Partido Ecológico Nacional - PNE, o Partido Solidariedade - SD, o Partido Republicano da Ordem Social - PROS, o Partido Novo - NOVO, a Rede da Sustentabilidade - REDE e, ainda ontem, o Partido da Mulher Brasileira - PMB” (ADI 5311).

Cabe destacar que Roberto Barroso expressa esse entendimento há pelo menos dez anos, quando o demonstrou na obra "A Reforma Política: Uma proposta de sistema de governo, eleitoral e partidário para o Brasil." Nela, afirma que "o sistema partidário permite a criação e a participação, no processo eleitoral, de partidos ditos de 'aluguel', sem qualquer compromisso doutrinário ou ideológico.” (BARROSO, 2006, p. 335)

Ainda acompanharam os argumentos da relatora, na ADI n⿳0 5311, os ministros Teori Zavascki, Celso de Mello, Rosa Weber, Gilmar Mendes, Ricardo Lewandowski e Luiz Fux. Fux destacou a importância da fidelidade partidária para combater essa fragilidade das legendas no país. Dias Toffoli, no entanto, manteve o entendimento expresso na ADI no 4430, afirmando pelo pluripartidarismo, além de defender "o estímulo constitucional à formação e ao desenvolvimento das agremiações partidárias como sujeitos do processo eleitoral". Nesse sentido, evidencia-se, entre a maioria dos membros do STF, uma indisposição à aceitação de regras que permitam a pulverização de ideologias partidárias, consubstanciada na criação indiscriminada de legendas sem forte programa ideológico que justifique assim suas criações. 


\section{Considerações finais}

É notável que a proliferação de partidos políticos no Brasil incomoda legisladores, doutrinadores e os próprios ministros do Supremo Tribunal Federal. A Constituição da República de 1988, inspirada pela superação dos anos de um governo não democrático, consagrou o pluralismo político como fundamento. Nas últimas três décadas, portanto, o país assistiu à criação e à extinção, além de mudanças de nome, de diversas agremiações partidárias. Todo esse processo encaminhou para o cenário político o número considerável de 35 partidos registrados no Tribunal Superior Eleitoral, com 69 processos de criação em tramitação em dezembro de 2017.

Tal fenômeno leva, diariamente, ao questionamento da situação de o sistema eleitoral representativo brasileiro chegar a um ponto de não retorno. Tendo em vista que a representação partidária surge com o objetivo de fortalecer as ideologias inerentes aos programas partidários, não se justifica a personalização da figura dos candidatos, incentivada muitas vezes pelo sistema de listas abertas, em que o mais votado ganha demasiada importância para a definição dos rumos do partido.

Dessa forma, o Supremo Tribunal Federal consolidou o entendimento de que o mandato pertence ao partido, noção já devidamente solidificada nos aspectos de legislação, doutrina e jurisprudência. No entanto, os reflexos da criação de uma nova legenda ainda representam desafios no contexto brasileiro. Quando se reconhece a importância da representatividade de todas as ideologias em uma democracia moderna, tende-se ao incentivo à liberdade de criação partidária. Entretanto, muito se pergunta se é possível termos tanta diversidade de pensamento que justifique um novo partido para acolher esse conteúdo programático. Não seriam os 35 existentes capazes de representar esse suposto novo conjunto de ideias?

O julgamento final da ADI no 5380 pelo Plenário do STF deve, finalmente, dirimir uma questão tão fundamental à democracia brasileira. Cabe fortalecer a criação de novos partidos, de modo que eles recebam, desde já, parlamentares em exercício de mandato eletivo? Ou deve prevalecer a janela de transferência aberta, durante trinta dias, sete meses antes das eleições proporcionais? Pela análise presente neste artigo, denota-se que a Suprema Corte brasileira tenderá a observar que as regras de justa causa para a infidelidade partidária, introduzidas pela Lei nº 13.165, de 29 de setembro de 2015, representam uma evolução natural e constitucional do sistema eleitoral brasileiro. 


\section{Referências}

ALMEIDA, Roberto Moreira de. Curso de direito eleitoral. 11. ed. Salvador: Juspodivm, 2017. 896 p.

AMADO, Gilberto. Eleição e representação. Brasília: Senado Federal, 1999.

ASSIS BRASIL, Joaquim Francisco de. Democracia representativa: do voto e do modo de votar. 4. ed. Rio de Janeiro: Imprensa Nacional, 1931.

BARROSO, Luís Roberto. A Reforma Política: Uma proposta de sistema de governo, eleitoral e partidário para o Brasil. In: Revista de Direito do Estado, n 3. Rio de Janeiro: Renovar. 2006.

BOBBIO, Norberto. As ideologias e o poder em crise. Tradução de João Ferreira. 4. ed. Brasília: UnB, 1999.

BONAVIDES, Paulo. Ciência política. São Paulo: Malheiros, 2012.

A Decadência dos Partidos Políticos e o Caminho para a Democracia Direta. In: Rocha, Cármen Lúcia Antunes; Velloso, Carlos Mário da Silva (Coord.). Direito Eleitoral. Belo Horizonte: Livraria Del Rey Editora, 1996.

BRASIL, Constituição (1988). Constituição da República Federativa do Brasil. Disponível em: <www.planalto.gov.br/ccivil_03/constituicao/constituicao.htm>. Acesso em: 5 dez. 2017.

BRASIL, Lei no $\mathbf{4} .737$, de 15 de julho de 1965. Código eleitoral. Disponível em: <http://www.planalto.gov.br/ccivil_03/leis/L9096.htm>. Acesso em: 5 dez. 2017.

BRASIL, Lei $\mathbf{n}^{\mathbf{9}} \mathbf{9 . 0 9 6}$, de 19 de setembro de 1995. Lei dos partidos políticos. Disponível em: < http://www.planalto.gov.br/ccivil_03/leis/ L9096. htm>. Acesso em: 5 dez. 2017.

BRASIL, Lei no $\mathbf{1 3 . 1 6 5}$, de 29 de setembro de 2015. Altera as leis [...] e incentivar a participação feminina. Disponível em: < http://www.planalto. gov.br/ccivil_03/_Ato2015-2018/2015/Lei/L13165.htm>. Acesso em: 5 dez. 2017.

BRASIL. Supremo Tribunal Federal. Ação Direta de Inconstitucionalidade. Processo no 3.999, Rel. Min. Joaquim Barbosa, Tribunal Pleno, julgado em 12.11.2008, DJe-071, 17 abr. 2009. Disponível em: <http://www. stf.jus.br/portal $/$ processo $/$ verProcessoAndamento.asp?incidente $=2584922>$. Acesso em: 10 dez. 2017. 
BRASIL. Supremo Tribunal Federal. Ação Direta de Inconstitucionalidade. Processo no 4.086, Rel. Min. Joaquim Barbosa, Tribunal Pleno, julgado em 12.11.2008, DJe-071, 17 abr. 2009. Disponível em: <http://www. stf.jus.br/portal/processo/verProcessoAndamento.asp?incidente $=2622952>$. Acesso em: 10 dez. 2017.

BRASIL. Supremo Tribunal Federal. Ação Direta de Inconstitucionalidade. Processo no 4.430, Rel. Min. Dias Toffoli, Tribunal Pleno, julgado em 12.11.2008, DJE nº 184, divulgado em 18/09/2013. Disponível em: $<$ http://www.stf.jus.br/portal/processo/verProcessoAndamento.asp?incidente $=3903848>$. Acesso em: 10 dez. 2017.

BRASIL. Supremo Tribunal Federal. Ação Direta de Inconstitucionalidade. Processo no 4.795, Rel. Min. Dias Toffoli, Tribunal Pleno, julgado em 29/06/2012, DJE no 215, divulgado em 29/10/2013 . Disponível em: $<$ http://www.stf.jus.br/portal/processo/verProcessoAndamento.asp?incidente $=4257995>$. Acesso em: 10 dez. 2017.

BRASIL. Supremo Tribunal Federal. Ação Direta de Inconstitucionalidade. Processo no 5.311, Rel. Min. Cármen Lúcia, Tribunal Pleno, liminar julgada 30/09/2015, DJE no 21, divulgado em 03/02/2016. Disponível em: $<$ http://www.stf.jus.br/portal/processo/verProcessoAndamento.asp?incidente $=4758587>$. Acesso em: $10 \mathrm{dez} .2017$.

BRASIL. Supremo Tribunal Federal. Ação Direta de Inconstitucionalidade. Processo no 5.398, Rel. Min. Roberto Barroso, medida cautelar. Despacho de 11/11/2015 (DJE n² 225, divulgado em 11/11/2015). Disponível em: <http://www.stf.jus.br/portal/processo/verProcessoAndamento. asp?incidente $=4867933>$. Acesso em: 10 dez. 2017.

BRASIL. Supremo Tribunal Federal. Mandado de Segurança. Processo no 26.602, Rel. Min. Eros Grau, Tribunal Pleno, julgado em 04.10.2007, DJe197, 17 out. 2008. Disponível em: < http://www.stf.jus.br/portal/processo/ verProcessoAndamento.asp?incidente $=2513855>$. Acesso em: 10 dez. 2017.

BRASIL. Supremo Tribunal Federal. Mandado de Segurança. Processo no 26.603, Rel. Min. Celso de Mello, Tribunal Pleno, julgado em 04.10.2007, DJe-241, 19 dez. 2008. Disponível em: <http://www.stf.jus.br/portal/processo $/$ verProcessoAndamento.asp?incidente $=2513846>$. Acesso em: $10 \mathrm{dez}$. 2017. 
BRASIL. Supremo Tribunal Federal. Mandado de Segurança. Processo no 26.604, Rel. Min. Cármen Lúcia, Tribunal Pleno, julgado em 04.10.2007, DJe187, 03 out. 2008. Disponível em: < http://www.stf.jus.br/portal/processo/ verProcessoAndamento.asp?incidente $=2514122>$. Acesso em: 10 dez. 2017. BRASIL. Tribunal Superior Eleitoral. Consulta. Processo no ${ }^{1.398}$, Resolução no 22.526, de 27 de março de 2007. Rel. Min. Francisco Cesar Asfor Rocha, DJ, v. 1, p. 143, 08 de mai. 2007.

BRASIL. Tribunal Superior Eleitoral. Resolução no 22.610/2007. Relator Ministro Cezar Peluso, 25 out. 2007.

BRASIL. Tribunal Superior Eleitoral. Resolução no $\mathbf{2 3 . 4 6 5 / 2 0 1 5}$. Relator Ministro Henrique Neves da Silva, 17 dez. 2015.

CARDOSO, José Carlos. Fidelidade Partidária. Rio de Janeiro: Lumen Juris, 1997.

CARVALHO, Paulo de Barros. O princípio da segurança jurídica em matéria tributária. Ciência Jurídica, ano 8, v. 58, p. 55-61, jul./ago. 1994.

CASTRO, Edson de Resende. Curso de direito eleitoral. 7. ed. Belo Horizonte: Del Rey, 2014.

CANOTILHO, José Joaquim Gomes. Direito constitucional e teoria da constituição. 3. ed. Coimbra: Almedina, 1998.

. Direito constitucional. 6. ed. Coimbra: Almedina, 1995.

FERREIRA, Luís Pinto. Princípios gerais do direito constitucional moderno. 4. ed. São Paulo, Saraiva, 1962, v. I.

JORGE, Flavio Cheim; LIBERATO, Ludgero; RODRIGUES, Marcelo Abelha. Curso de direito eleitoral. 2. ed. Salvador: Juspodivm, 2016.

MENDES, Gilmar Ferreira. Reforma eleitoral: perspectivas atuais. Estudos Eleitorais, Brasília, v. 11, n. 3, p. 11-41, set./dez. 2016.

MILL, John Stuart. Governo Representativo. Tradução: E. Jacy Monteiro. São Paulo: Ibrasa, 1964 [1861].

MORAES, Alexandre de. Constituição do Brasil interpretada. 5. ed. São Paulo: Atlas, 2005.

NICOLAU, Jairo M. Sistemas Eleitorais. 5. ed. rev. e atual. Rio de Janeiro: Editora FGV, 2004. 
RIBEIRO, Fávila. Direito eleitoral. 5. ed. Rio de Janeiro: Forense, 1998.

SILVA, José Afonso da. Comentário contextual à Constituição. São Paulo: Malheiros, 2009.

TELLES JÚNIOR. Goffredo. A Democracia Participativa. In: Revista da

Faculdade de Direito. Universidade de São Paulo, vol. 100, 2005.

Rodrigo Élcio Marcelos Mascarenhas - Mestre em Administração Pública da Escola de Governo da Fundação João Pinheiro. Bacharel em Comunicação Social - Jornalismo pela Universidade Fumec. Bacharel em Direito pela Universidade Fumec. Analista Legislativo jornalista da Assembleia Legislativa de Minas Gerais. Advogado.

Leônidas Meireles Mansur Muniz de Oliveira - Doutorando em Direito pela Pontifícia Universidade Católica de Minas Gerais. Mestre em Direito Empresarial pela Faculdade de Direito Milton Campos (bolsista FAPEMIG). Bacharel em Direito pela Pontifícia Universidade Católica de Minas Gerais (PUC-MG), Especialista em Direito e Processo do Trabalho. Coordenador do Curso de Direito da Faculdade Pitágoras Cidade Acadêmica de Belo Horizonte, Professor de Direito do Trabalho e Processo do Trabalho, Direito Empresarial e Metodologia da Pesquisa Científica. 